\title{
Comparison of gavage, water bottle, and a ligh-moisture diet bolus as dosing methods for quantitative $D$-xylose gdministration to B6D2F1 (Mus musculus) mice
}

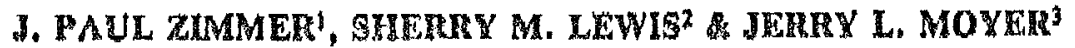 \\ 1 \\ 'Divislon of Nutrillonal Sciences, Cormell Unlyerslty, Ihaca, NY 14850; ${ }^{2}$ The Blonatics Curporalion, National \\ Center for Toxlcologleal Research, Jefferson, AR 72079; and The Blonetics Corporatlon, NASA, Kennedy . \\ Space Center, FL 32899, USA
}

Surnatsry

Gavage, water bottle, and dlet incorporation are 3 dosing muthods used orglly to administer test compounds to rodents. These 3 methods were compared in mice to determine which represented the most quantitative delivery system. For distury incorporation, a hlghm molsture bolus form of NIH-31 rodent menl was developed uaing hydroxypropyl methylcellulose as an autoclavesstable bloding agent. A highmoisture balus was selected to Inereate the acceptabllty of the dosed diet and to promute quantitative consumption through reduced wastage. The test compound used was $\mathrm{D}-\mathrm{xylose}$, - pentose sugar that may be quantitatively detected, colorimetrically, In urine following oral dosing. Six male and 6 femalo B6D2Fi mice were placed in metabollsm cages und dosed with a known quantity of D-zylose by ench of the 3 methods. Urine was collected before and after ezch method of adminlstration and analysed for total D-xylose; the per cent recovery was besed upon the smount of D-mylose consumed. Quantitative consumption was apparently greatest for water bottle dosing with an average recovery of $56.0 \%$ of the original D. xylose dose. High-molsture bolus Incorporation ranked second with $50.0 \%$ D-xylose recovery, and gavage was third with $41.0 \%$ D-xylose racovery.

Corrospandense to: Dr SM Lewir.

Rácelued 18 Decomber 1901; acceptad 9 Octaber 1992
Keywords: Dosing methods; Kighomoisture dlet; Meal; Gavage; Water bottle; D-xylose; Xylose tolerance test

A major cencern in dosing rodents with test compounds is the accurate quantification of oral delivery. The water bottle delivery method continuously supplies water-soluble compounds over a period of time. Problems llmiting the usefulness of water bottles include test compound palatability and solubility, splllage (Lang et al., 1984), soundness of the bottle stopper, leaching of compounds from the stopper (Kennedy \& Beal, 1988), and individual variations in water demand (Weisburger Weisburger, 1967). Gavage delivers a known quantity of test compound in a single dose. The disadvantages of gavage dosing include oesophngeal or stomach damage, intubation of the lungs, and large, potentially fatal splkes in test compound plasma concentration (Weisburger \& Weisburger, 1967; Lindanood ef al., 1988). The gavage dosing of animals is also very labour-intensive.

High-moisture diets contain a binder that combines water and the diet meal into a semisolid mixture. This mixture is a usaful method for presenting dusty, volatile, or toxic test compounds to animals with minimal spllage and wastage, thus reducing the risk of exposure to toxic test compounds to the technienl staff (Lang et al., 1984; Clapp \& Bradbrook, 1982). If the test compound is pre-mixed into a soluble diet ingredient, such as lipophilic compounds mixed 
with the fat component, water-soluble or -inboluble compounds cari be incorporated into the diet (Welsburger \& Welsbutger, 1967). Studies using hlgh-moisture, semi-purified diets containing agar as a binder have been successfully used to feed mice (Lang et al, , 1984), rats (Clapp \& Bradbrook, 1982), and guineapigs (Navia \& Lopez,

- 1973). Recent studies show agar Induces nonpathological, physiological changes in caecurn and colon cell growth; however, it may promote the " carcinogenicity of certain compounds (Shiau Wang, 1988). Compared with gavage, dosed diets have been used to deliver higher levels of an unpalatable and highly toxic compound with a reduced mortality rate (Lindamood et ol., 1988).

The objectives of this study were to develop a high-moisture, natural-ingredient dietary form useful for tficiently providing test compounds in a pre-feeding bolus, and to compare it with gavage and water bottle methods for efficlency in oral delivery of a known quantity of D-xylose to B6D2F1 mige. The bolus was formulated with a commercial food binder and tested for accept. ability by male and female B6D2Fl mice ( $M$ us muscu(us), D-Xylose, a pentose suger, was chosen as a test compound based on its water solubility, rapid urlnary clearance (Cralg \& Atkinson, 1988), lack of toxic effects, ease of detection (Eberts et al., 1979), and because its sbsorption from the intestinal tract is proportional to the dose given (Stradley et al., 1986).

\section{Materlals and methods}

High-moisture diet formulation

Eight food-processing companies supplied 20 commercial food binders for this study. The classes

Table 1. Commerelal food binderi evaluated

\begin{tabular}{|c|c|c|c|}
\hline Product nume & Blnding agent & Selecled binder & $\begin{array}{l}\text { Commercial } \\
\text { source }\end{array}$ \\
\hline$H-50$ & Cassuva starch & + & 1 \\
\hline $11 \cdot .131$ & Caksava \$larch & - & 1 \\
\hline National $78-1272$ & Cassura starch & - & 1 \\
\hline Rodisol 412 & Cassuva sturch & - & 2 \\
\hline Redisol 248 & Potalo starch & - & 2 \\
\hline Thln-n-ThIk 99 & Corn starch & - & 2 \\
\hline Sta-Mist 369 & Corn sthroh & - & 2 \\
\hline Sta-Mist 454 & Corn starels & - & $\overline{2}$ \\
\hline Methocel (MC) & Methylcellulose & - & 3 \\
\hline Methocel (HPMC) & Hydroxypropyl mathylecllulose & + & 3 \\
\hline CMC R.75-H4 & Sodlum tarboxymathylcellulose & + & 4 \\
\hline CMC R.95.H4 & Sodlum carboxymethylesellulose & - & $A$ \\
\hline Avicel PH-10I & Microcrystalline cellulose & - & 5 \\
\hline Avicel RC-5yIf & Miçroctystalline cellulost & - & 5 \\
\hline Rhodlgel & Xanthen gum & - & 6 \\
\hline Polydextrose & Dexirase polymer & - & 7 \\
\hline 1701 Doxtrin & Corn dextrin & - & 8 \\
\hline Lo.Dex 10 & Corn malto-dextrin & - & 8 \\
\hline 1620 Dexirln & Corn doxtrin & - & $\mathbf{y}$ \\
\hline 7710 Dextrin & Corn dextrin & - & 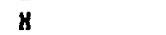 \\
\hline
\end{tabular}

"Hinders were setceted based upon selectlon criterlon pre-estabtished lor this research; selection is not a test of product endorsement.

"National Starch and Chemical Corp., Brldgewater. NJ.

${ }^{2} A$. E. Staley Manufacturing Decatur, IL.

"Jow Chemlesl, Midland, ML.

Loulsian Chemlital Polymers, Baton Rouge, LA.

'FMC Corporation, Philadelphia. PA.

-Rhone-Poulone, Moninoulh Junction, NJ.

'Pfizer Chemlcal Dlulsion, New York, NY.

American Maize-Products, Hammond, IN.

+ Acceplable or - non-aceoptable by test orlteria. 
of binders supplied were as follows: chemicallymodified and unmodified tapioca starches, modified and unmodified corn starches, modified potato starch, hydroxypropyl methylcellulose, methylcellulose, microcrystalline cellulose, sodium carboxymethylcellulose, xanthan gum, polydextrose, malto-dextrin, and modified dextrins (Table 1).

Autoclave stability of the binders and their usefulness in high-moisture diet applications were determined by practical tests. Various combinations and varying proportions of binder, diet and water were autoclaved to determine physical stability and qualitative properties of the diet bolus formed. Binders were first autoclaved individually to determine their ability to retain pre-autoclaving form and consistency, Blinders exhiblting physical changes or deterioration after autoclaving were eliminated from further consideration (Table 1).

Binders exhiblting stable properties were then autoclaved with ground ( 20 mesh) NIH-31 standard rodent diet (Purina Mills Inc., Richmond, IN) In dry premixes containing 1,5, or 10\% binder, by weight. The NIH-31 diet was chosen as it remains physically stable when autoclaved and is a natural-ingredient, completely balanced diet. Animals were maintained on pelieted NIH -31 diet when not on test. Dry premixes that did not undergo physical changes or deterioration wore then hydrated with $5 \mathrm{ml}$ aliquots of water, added incrementally, and hand-mixed until a bolus was formed. If a cohesive bolus did not form when a total of $15 \mathrm{~m} /$ had been added to the dry premix, no further water was added.

Mixtures of binder, diet, and water were then formulated for autoclaving and evaluation. Mixtures contained 1, 5, or $10 \%$ of binder by weight. Water, as 33,50 , or $60 \%$ of the total weight, was added to the dry ingredients prior to autoclaving, resulting in 9 samples tested per binder. Binders to be tested for animal acceptabllity represented 3 chemical classes and were superior in autoclave stability and cohesive propertles. The 3 binders selected were Methocesto hydroxypropyl methyleellulose (Dow Chemical USA, Midland, MI), CMC R-75-H4 carboxy- methylcellulose (Louisiana Chemical Polymers, Baton Rouge, LA) and H-50 modified cassava starch (National Starch \& Chernical Corp., Bridge water, NJ). The 3 mixtures used in the animal acceptability evaluation were: (1) a $1: 3: 5$ ratio of binder: diet: water using cassava starch; (2) a 1:5:7 mixture using hydroxypropyl methylcellulose; and (3) a 1:5:7 mixture using carboxy- * methylcellulose (Table 1),

\section{Evaluation of animal acceptability}

An acceptability trial was conducted to test the boluses using 125 -month-old B6D2F1 mice of conventional microbiological status. Animals were allocated to one of 3 groups, 2 males and 2 females in each group. All animals were acquired from the Natlonal Center for Toxicological Research, Jefferson, AR, Breeding Facility. The boluses contained $1 \mathrm{~g}$ of ground (20 mesh) NIH-3I diet hand-mixed with binder and water in the ratios determined in the previous stage of testing. Environmental conditions of the animal rooms were $23 \pm 1 \cdot 5^{\circ} \mathrm{C}$ temperature, $50 \pm 9 \%$ relative humidity, automatic $12: 12$ light: dark cycle (lights on at $0600 \mathrm{~h}$ ), and HEPA filtered air with $10-15$ exchanges/h. The animals were individually housed; food and water was available ad libilum before and after the testing. The mice were fasted for $24 \mathrm{~h}$ immediately prior to testing to promote complete and rapid consumption of the bolus. Polycarbonate shoebox cages were modifled for the test by gluing a small, preweighed beaker containing the bolus to the cage wall oneminch from the floor to prevent contamination of the bolus with facces or urine. Bedding was removed from the cages during the $1 \mathrm{~h}$ of exposure to the bolus in order to accurately observe the animals' acceptance. The animals were continuously observed to determine quantity consumed and wastage or spillage of the bolus.

\section{Evaluation of dosing efficlency}

Twelve male and 12 female 5 month-old B6D2F1 mice were used in this section of the study. Environmental conditions were the same as in the evaluation of animal acceptabllity. The animals were allocated to 2 replicate groups of 
6 males and 6 females. While one group was being tested; the other group was housed in polycarbonate shoebox cages with ad Ibitum food and water provided. During collection intervals, animals were housed in polycarbonate metabolism cages (Maryland Plastics Inc., Federalsburs, MD) and acclimatized for 3 days prior to the trial.

The test was conducted in consecutive treatment order with each animal receiving all treatments with intervening intervals in which the effects of the previous treatment were determined by urine assay as described below. Testing of the high-rnoisture bolus, water bottles, and gavage was performed in consecutive 4-day periods. Wrine was collected on the first day (Day 0) of each period to satablish baseline $D$-xylose excretion values and to confirm that D-xylose excretion had returned to baseline values before beginning another treatment. The dose was provided after baseline urine samples were collected and analysed. Urine was collected for 3 consecutive days following dosing to ensure complete recovery of the D-xylose. To prevent bacterlal growth in the urine samples, $0.2 \mathrm{ml}$ of a $10 \%$ thimerosal solution (Aldrich Chemical Co., Milwaukee, WI) was added to each sample prlor to analysis (J Knowles, personal communlcation).

The high-moisture diet bolus, $63 \%$ dry matter, contained $1.0 \mathrm{~g}$ ground ( 20 mesh) NIH-31 rodent meal, 0.1 \& Methocel@hydroxypropyl methylcellulose as the binder, and $1.6 \mathrm{ml}$ of $\mathrm{a} .6 .258$ D-xylose $/ 100 \mathrm{ml}$ water solution to provide $0.1 \mathrm{~g}$ D-xylose/dose. The boluses were mixed by hand and provided to the mice for $24 \mathrm{~h}$. Consumption was megsured as change in weight of the beaker and contents. No spillage or wastage was noted. Water was available ad libilum throughout this treatment. The NIH-31 pelleted diet was returned following bolus consumption.

The water bottle dose consisted of $1.0 \mathrm{~g} D$. xylose in $100 \mathrm{ml}$ water placed in the water bottles for a 24-h period. Intake was represented as a change in weight of the water bottle and contents. The concentration of D-xylose consumed was then calculated. Fresh water was returned after the treatment. NIH-31 pelleted diet was available ad libilum throughout this treatment.

The gavage dose was $0.5 \mathrm{ml}$ of a $5.0 \mathrm{~g} D$ xylose $/ 50 \mathrm{ml}$ water solution $(0.05 \mathrm{~g} \mathrm{D}$-xylose/ dose) administered vie syringe and blunt-ended gavage needle. Water and NIH-31 pelleted diet were available ad libilum throughout this treatment.

\section{Sample analysis}

The urine samples were analysed using a modified colorimetric method of Eberts (Eberts et al, 1979) in which benzoic acid was omitted from the assay. Five standards containing 0.5 , $1 \cdot 0,2 \cdot 5,5 \cdot 0$ and $10.0 \mathrm{mmol} / 1$ of $\mathrm{D}$-xylose were prepared to establish daily calibration curves. Consistent linear calibration curves were estab. lished using standards prepared by the modified procedure. Samples were prepared in $35 \mathrm{ml}$ screw-top tubes with Teflon(s-lined caps and incubated in a boiling water bath. When the D-xylose content of a sample was below detection limits, the assay was repeated using 2 or 4 times the urine concentration to achieve a measurable D-xylose concentration. Results were adjusted for the increased urine concentrations. All samples were run in triplicate and averaged, samples were reanalysed if the variance exceeded $10 \%$.

\section{Statistical anaiysis}

The maln effects of sex and treatment upon Dxylose recovery between replications were the factors considered. Statistical analyses were performed by using analysis of variance obtained from the General Linear Models procedure of Statistical Anzlysis Systems (SAS, 1982) using least squares calculation of treatment means and Foprotected comparisons. Tukey's test was also employed to verify multiple means comparisons.

\section{Results}

Evaluation of animal acceptability

The criteria for evaluating the boluses were: (1) consumption by the mice and, (2) cohesive integrity of the bolus while the mice were feeding. The bolus containing cassava starch was consumed 
by half of the mice and showed high cohesive Integrity. The bolus containing the carboxymethylcellulose was consumed by all of the mice but showed poor cohesive integrity. The bolus containing hydroxypropyl methylcellulose was consumed by 3 of the 4 mice and showed high cohesive integrity. Based on these results, hydroxypropyl methylcellulose was selected for use in the bolus preparation for further testing. Hydroxypropyl methylcellulose has been proven safe for long- and short-term use with rodents (WHO, 1974),

\section{Evaluation of dosing efficlency}

The recovery efficiency of each dosing treatment was calculated as per cent of the original $D$. xylose dose which was recovered in the urine samples. The average $D$-xylose dose received by each animal was $0.091 \pm 0.010 \mathrm{~g}$ for animals consuming the high-moisture bolus, $0.042 \pm$ $0.012 \mathrm{~g}$ for animals receiving water bottles, and $0.05 \mathrm{~g}$ for gavaged animals (no variance). Two male mice died during the study. During the first replication, one mouse died from unknown causes after the final water bottle treatment period. During the second replication, one mouse died from accidental intubation of the lungs during the gavage procedure. Statistically, the losses only reduced the observations for the gavage comparison where $n=11$ for the males.

As there was no statistical difference due to replication, results were pooled for comparison of per cent $D$-xylose recovery by sex and treatment (Table 2). Females had significantly higher $\mathrm{D}$-xylose recoveries than males for all

Table 2. Per cent recovery of 10ial xylowe dosa from highmolvture buluk, gaveyo and water botlle treatintent amone s-munib-old BoD2FI mles

\begin{tabular}{|c|c|c|c|}
\hline Sex & $\begin{array}{l}\text { Treatment } \\
\text { High } \\
\text { moisture } \\
\text { bolus }\end{array}$ & Oavaze & $\begin{array}{l}\text { Water } \\
\text { bottle }\end{array}$ \\
\hline $\begin{array}{l}\text { Female } \\
\text { Male }\end{array}$ & $\begin{array}{l}54 \cdot 1^{2} \\
46 \cdot 0^{4}\end{array}$ & $\begin{array}{l}47 \cdot 1^{b} \\
35 \cdot 5^{b}\end{array}$ & $\begin{array}{l}59 \cdot 6^{\prime \prime} \\
52 \cdot 3^{\circ}\end{array}$ \\
\hline
\end{tabular}

a.tMeans In a row with different superserlpts differ $(P \times 0.05)$.
Table 3. Per cent dally xylose recovery from hlgh-moluture bulus, gavage and water bottle treatmenls amung s-moath* ald B6D2F1 mles

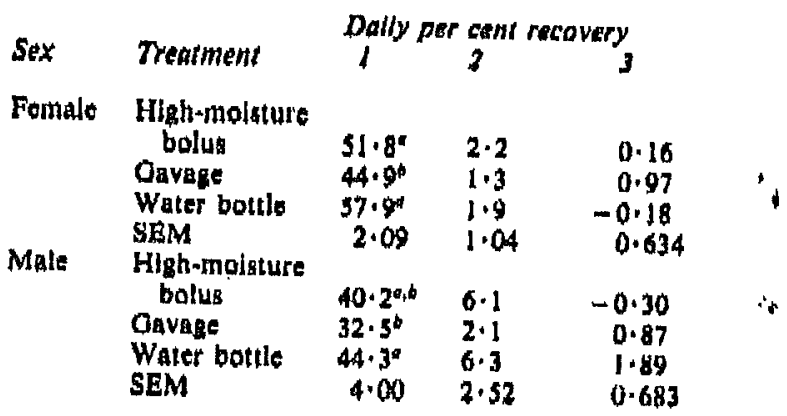
$R, b$ Means in a column with different superseripis differ
$(P<0 \cdot 05)$.

methods tested. Recovery among females for the high-moisture bolus, gavage and water bottle treat. ments differed $P<0 \cdot 10, P<0.01$ and $P<0.05$, respectively, as compared with male recoverles. Among females, significantly higher $(P<0.05)$ total D-xylose recoveries were found for the water bottle and high-moisture bolus methods, 59.6 and $54.1 \%$, respectively, as compared with gavage, 47. 1\%. Annong males, significantly higher $(P<0.05)$ total $D$-xylose recoverles were found for the water bottle and high-moisture bolus methods, 52.5 and $46.0 \%$, respectively, as compared with gavage, $35 \cdot 5 \%$. The trends for both sexes showed a simllar hierarchy due to treatment (water bottles $>$ high-moisture bolus $>$ gavage),

The D-xylose recoveries for the first day (Table 3) following each treatment showed significantly $(P<0.05)$ greater recoveries for the highmoisture bolus and water bottle treatments as compared to gavage dose recovery, 5$] \cdot 8$ and $57.9 \%$ vs $44 \cdot 9 \%$, respectively. For males, water bottle and high-moisture bolus treated animals demonstrated significantly $(P<0.05)$ more efficient first day D-xylose recoveries than gavage, $44 \cdot 3$ and $40 \cdot 2 \%$ vs $32 \cdot 5 \%$, respectively. Essentially, all D.xylose tecovery was complete by 2 days post-treatment.

Discussion

The 3 methods for oral administration of test compound used in this study have various 
advantages and digadvantages that determine their suitability for a study. When the comparative efficiency of gavage, water bottles, and a novel high-moisture bolus in delivering a known quantity of D-xylose 10 male and female B6D2F1 mice was analysed, water bottle delivery demonstrated the highest $D$-xylose

- dosing efficiency and recovery of the 3 methods. However, the efficiency of the high-moisture bolus delivery was not statistically different from that of the water bottles.

For each dosing method tested, there are associated disadvantages. For the high-moisture bolus, the bolus must be given separately from normal feeding regimens, requires added labour, and a prefast interval to ensure complete consumption. For the water bottles, dose loss due to spillage is a commonly cited disadvantage (Lang ef al., 1984). In this study, one animal died after accidental intubation of the lungs following gavage.

It is not known whether the binder used in the high-moisture bolus had any inhibitory effect on D-xylose absorption; however, gel-forming gums, including carboxymethylcellulose, have been shown to reduce $D$-glucose transport in the rat jejunum (Johnson \& Gee, 1981). If D-xylose and D-glucose share a common transport pathway, as suggested by some researchers (Ohkohchi \& Himuki, 1984), the inhibition of transport by the hydroxypropyl methylcellulose gel used could have reduced the efficiency of D-xylose absorption from the high-molsture bolus. Based on D-xylose absorption studies using rats, the minor differences in concentrations of D-xylose provided by the gavage and water bottle solutions $(0.05$ and $0.042 \mathrm{~g}$, respectively) should ndot have changed the proportion of D-xylose absorbed (Stradley et al., 1986).

The greatest recovery for $D$-xylose observed in this study was an average $56 \%$ following water bottle administration (Table 2). Earlier researchers (Segal \& Foley, 1959) report that labelted $D$-xylose infusion in man resulted in an average $44 \%$ urinary recovery of the total dose. These researchers proposed that the pentose sugars may be converted, in part, to glucose or may enter glycogenesis via the pentose phosphate pathway. This latter conversion had been reported to occur in the intact mouse (Hiatt, 1957).

A significant sex difference was seen in all treatments in which D-xylose recovery among females was consistently higher than among males. A study investigating sex differences in human D-xylose excretion found a tendency among females to excrete $D$-xylose more efficiently than males after an intravenous dose (Kendall \& Nutter, 1970). Similar research has not been previously conducted for mice.

As gavage dosing is widely used as a method of chemical administration, the results reported here are of particular interest. The comparison of other compounds among the 3 dosing methods is warranted to provide more information about the recovery efficiencies of the methods studied.

Xylose is the chief pentose that is actively absorbed from the gut (Roehrig, 1984). Absorption of the total D-xylose dose may have been inhibited by the saturation of the actlve transport system. Although D-xylose was selected for its previously reported stability, perhaps this pentose sugar is metabolized as previously suggested (Hiatt, 1957).

The summarized data show that both water bottles and the high-moisture bolus are comparable in delivering a known quantity of Dxylose to mice. Water bottles showed a consistently higher, but not significantly different, efficiency than the high-moisture bolus, but the method is limited to water-soluble compounds. The high-moisture bolus is more versatile with regard to compound solubility,

\section{Acknowledgments}

The authors would like to express their appreciation to the Office of Restarch Services, especially the Divisions of Microbiology and Chemistry, at the National Center for Toxicological Research for support in this research. 


\section{Referencen}

Clapp MJL \& Bradbrook C (1982) Growth and longevity of rats fed an agar-bound diet. Laboratory Animals 16. $138-142$

Cralg RM Atkinson AJ (1988) D-xylote cesing: A revlew. Gustroenterology $\$ 5,223-231$

Eberr TJ, Sample RHB, Olick MR, ef al. (1979) A simplified, colorimetrlo nilcromethod for xylose in serum or urine, with phloroglucinol. Clinical Chemistry 25, 1440-1443

Hlatt HH (1957) Glycogen formation vis the pentose phosphate pathway in mies in vivo. Journal of Blologltal Chemistry 224, 851-859

Johnson IT \& Oed JM (1981) Effect of gel forming gums on tho intestinal unstirred layor and sugar trarseport in vitro. ON1 32, $398 \div 403$

Kendall MJ Nutter $S(1970)$ The inlluence of sex, body weight, and renal punction on the xylose test, Gui 11, $1020+1023$

Kennedy BW \& Beal TS (1988) Mineral contribution to drinking water from rubber stoppers. Luboratory Animal Solence 38, 497-498

Knowles J. National Center for Toxleological Research, Microbiology Division. Pertonal communictation

Lang JA, Lang CM \& White WJ (1984) Uat of agar-bated diet to fultif the food and water requirements of mice. Laboratory Animols 18, 40-41

Lindamood C, Lamb JC: Bristol DW, ef al. (198B) Studies on the short-term toxjolly of theophyillne in rass and mloe. Fundomintal and Applied Toxicology 10, 477-489
Navla JM \& Lopez H (1973) A purified gel diet for guinea pigs, Laboratory Animal Solunce 23, 111-114

Ohkohchi N H Himukal M (1984) Specles difference in mechanisms of $\mathrm{D}$-xylose absorption by the small intestine. Japonese Journal of Physiology 34, 669-677

Roehrlg KL (1984) Digestion of simple curbohydrates. In Carbohydrate Blochemisiry and Melabolism. Wesiport CN: AVI Publishing Company, Inc.

Sezal is \& Foley JB (1959) The metabolic fate of $\mathrm{C}^{14}$ labeled pentoses in man. Amerlcan Journal of Clinical Investigo. iton $38,407 \mathrm{~m} 413$

Shlau SY \& Wany HJ (1988) Effects of dletary agar on rat colonic und cecum mucosal growsh. Nuerfilion Reports Internutlanul 38. 147-159

Stallstical Analyyis Sysiems. The GLM Procedure (1982) In: SAS Usuris Oulde: Statistiss, Version 5, Cary, NC: Stutlatical Analysis Systems Intitute, Ina., 433-306

Stradley R, Farmer-Bailey P, Pasquini $N$, et al. (1986) Castric absorption of $D$-xylose in the rat: its influence on the $D$. xylose absorption tess. Journal of Laboralory and Clinical Medicine 107, 10-14

Weisburger JH \& Weisburger EK (1967) Tests for chemical carchouens. In: Methods in cancer ressurth, Vol I ed. $H$ busch) pp. 307-398. New York. NY: Acudemle Pretis World Health Orgunizatlon (1974) Toxicolozirol evaluation of same foud udditives Including anticuking agents, antimicrobluls, ontioxidants, emulslliters und hickening agents. WHO Report WI W14H no 5, 247-315 